\title{
INDUCED SIMPATHETIC STIMULATION DURING HALOTHANE ANAESTHESIA
}

\author{
R. A. MillaR, M.D.(Edin.), M.Sc., F.F.A.R.C.S., and M. E. Morris, M.D.C.M. ${ }^{1}$
}

GANGLIONIC BLOCK.IDE, at first considered to be the principal factor in the hypotensive action of halothane (12), was later shown to play only a subsidiary role; direct myocardial and vascular depression and central vasomotor inhibition were considered to be of greater importance $(2,3,13)$. It has been suggested, however, that autonomic depression and even a protective action against shock are features of halothane anaesthesia $(6,7)$ although the mechanisms and evidence behind any such effects have not been defined.

Previous experiments in dogs lightly anaesthetized with thiopental have demonstrated increases mainly in plasma adrenalin as a result of haemorrhage (8) and rises in both noradrenalin and adrenalin during carbon dioxide accumulation (10). In this study an attempt has been made to assess whether sympathetic activity is depressed or abolished in dogs subjected to blood loss or hypercarbia during a steady state of halothane anaesthesia.

\section{METHOD}

Alter induction of anaesthesia in dogs with minimal amounts of thiopental ( 2.5 per cent), the trachea was intubated with a No. 10 cuffed rubber Magill tube, and positive pressure ventilation $\left(+10\right.$ to $\left.15 \mathrm{~cm} . \mathrm{H}_{2} \mathrm{O}\right)$ was started, using a Bird respirator (Marks 4 and 8 ) into which a $5 \mathrm{~L} . / \mathrm{min}$. flow of 100 per cent oxygen was delivered; a Ruben valve prevented rebreathing. One femoral artery was camnulated for direct blood pressure recording and withdrawal of blood samples. Heparin (Connaught Laboratories), $10 \mathrm{mg}$. $/ \mathrm{kg}$., was injected intravenously.

Following an initial period of ventilation with 100 per cent oxygen, during which further injections of thiopental were rarely required, control blood samples were withdrawn. These comprised $35 \mathrm{ml}$. for assay of plasma adrenalin and noradrenalin, essentially as described (9) and $8 \mathrm{ml}$. (withdrawn anaerobically) for determination of whole blood $\mathrm{pH}, \mathrm{pCO}_{2}$, and "standard" bicarbonate of plasma by the method of Astrup (1). Throughout every experiment an equal volume of normal saline solution was given intravascularly after each blood sampling.

Halothane was administered by redirecting the oxygen flow through a Fluotec vaporiser. Mark II, which was set to deliver a 2 per cent or higher concentration. In twelve studies, blood samples were withdrawn after 30,60 , and $120 \mathrm{~min}$. of uncomplicated halothane anaesthesia, during which respiration was controlled without the use of muscle relaxants. Thereafter, in seven experiments,

\footnotetext{
'Department of Anaesthesia, Montreal Neurological Institute, and McGill University, Montreal, P.Q.
} 
10 or 20 per cent carbon dioxide in oxygen was delivered to the system via the Fluotec vaporiser, following which spontaneous respiration was resumed, usually in less than 1 min. Blood samples for laboratory estimations were then withdrawn after a further 15,30 , and $60 \mathrm{~min}$. of anaesthesia. In the other five experiments, controlled ventilation with 2 per cent halothane in oxygen was continued while the animals were subjected to a haemorr hage of $20 \mathrm{ml} . / \mathrm{kg}$., followed later by a second haemorrhage of $12-18 \mathrm{ml} / \mathrm{kg}$. Blood samples were withdrawn for estimation 15-20 min. after each haemorrhage. During the periods of hypercarbia or haemorrhage the inspired halothane concentration was not reduced except for brief periods when a state of extreme hypotension indicated that circulatory collapse was imminent.

\section{RESULTS}

The first parts of Tables I and II show that during the 2-hour period of controlled ventilation with 2 per cent halothane in oxygen, preceding hypercarbia or haemorrhage, a moderate respiratory alkalosis was maintained with a quite constant level of $\mathrm{pCO}_{2}$. During this steady state small increases and decreases in

TABLE I

Average Data, in Six Experiments during a 60 Min. Period of Hypercarbia following 120 Min. of Steady Halothane Anaesthesia

\begin{tabular}{|c|c|c|c|c|c|c|c|c|}
\hline \multirow[b]{2}{*}{$\begin{array}{l}\text { Time } \\
\text { (min.) }\end{array}$} & \multirow[b]{2}{*}{$\mathrm{pH}$} & \multirow[b]{2}{*}{$\begin{array}{c}\mathrm{pCO} \\
(\mathrm{mm} \cdot \mathrm{Hg})\end{array}$} & \multirow[b]{2}{*}{$\begin{array}{l}\text { "Standard" } \\
\text { bicarbonate } \\
\text { (m-mole/L.) }\end{array}$} & \multirow[b]{2}{*}{$\begin{array}{l}\text { Adrena- } \\
\text { lin } \\
(\mu \mathrm{g} \cdot / \mathrm{L} .)\end{array}$} & \multirow[b]{2}{*}{$\begin{array}{c}\text { Nor- } \\
\text { adrenalin } \\
(\mu \mathrm{g} . / \mathrm{L} .)\end{array}$} & \multicolumn{2}{|c|}{ Arterial B.P. } & \multirow[b]{2}{*}{$\begin{array}{l}\text { Heart } \\
\text { rate }\end{array}$} \\
\hline & & & & & & \multicolumn{2}{|c|}{$\begin{array}{l}\text { (mm. Hg) } \\
\text { (mmic }\end{array}$} & \\
\hline Control & 7.50 & 28.3 & 21.1 & 0.22 & 0.30 & 154 & 92 & 101 \\
\hline$+30^{\prime}$ & 7.53 & 29.2 & 22.6 & 0.39 & 0.26 & 101 & 57 & 94 \\
\hline$+60^{\prime}$ & 7.51 & 27.6 & 20.7 & 0.32 & 0.57 & 98 & 55 & 94 \\
\hline$+120^{\prime}$ & 7.51 & 25.5 & 20.1 & 0.33 & 0.28 & 100 & 60 & 89 \\
\hline \multicolumn{9}{|c|}{ CARBON DIOXIDE $(10$ or $20 \%)$} \\
\hline$+15^{\prime}$ & 7.03 & 113 & 24.4 & 0.71 & 0.93 & 105 & 49 & 115 \\
\hline$+30^{\prime}$ & 6.97 & 141 & 25.4 & 1.9 & 1.3 & 106 & 45 & 114 \\
\hline$+60^{\prime}$ & 6.94 & 153 & 25.7 & 3.6 & 1.7 & 105 & 46 & 115 \\
\hline
\end{tabular}

TABLE II

Average Data, in Five Experiments, during a Period of Haemorrhage following 120 Min. of Steady Halothane Anaesthesia

\begin{tabular}{|c|c|c|c|c|c|c|c|c|}
\hline \multirow[b]{2}{*}{$\begin{array}{l}\text { Time } \\
\text { (min.) }\end{array}$} & \multirow[b]{2}{*}{$\mathrm{pH}$} & \multirow[b]{2}{*}{$\begin{array}{c}\mathrm{pCO}_{2} \\
(\mathrm{~mm} . \mathrm{Hg})\end{array}$} & \multirow{2}{*}{$\begin{array}{l}\text { "Standard" } \\
\text { bicarbonate } \\
\text { (m-mole/L..) }\end{array}$} & \multirow[b]{2}{*}{$\begin{array}{l}\text { Adrena- } \\
\operatorname{lin} \\
(\mu \mathrm{g} . / \mathrm{L} .)\end{array}$} & \multirow{2}{*}{$\begin{array}{c}\text { Nor- } \\
\text { adrenalin } \\
(\mu \mathrm{g} . / \mathrm{L} .)\end{array}$} & \multicolumn{2}{|c|}{ Arterial B.P. } & \multirow[b]{2}{*}{$\begin{array}{c}\text { Heart } \\
\text { rate }\end{array}$} \\
\hline & & & & & & \multicolumn{2}{|c|}{$\begin{array}{c}\text { Systolic Diastolic } \\
(\mathrm{mm} . \mathrm{Hg})\end{array}$} & \\
\hline Control & 7.53 & 29.8 & 24.2 & 0.28 & 0.22 & 163 & 80 & 97 \\
\hline$+30^{\prime}$ & 7.56 & 25.6 & 22 & 0 . & & 106 & & 84 \\
\hline$+60^{\prime}$ & 7.52 & 26.6 & 21. & 0.1 & 0 . & 10 & & 87 \\
\hline$+120^{\prime}$ & 7.53 & 25.6 & 21.3 & 0.22 & 0.43 & 96 & $\sqrt{x}$ & 89 \\
\hline \multicolumn{9}{|c|}{ HAEMORRHAGE } \\
\hline$+20^{\prime}$ & 7.48 & 25.2 & 18.7 & 0.70 & 0.32 & 60 & 28 & 88 \\
\hline$+40^{\prime}$ & 7.37 & 25.8 & 15.2 & 7.5 & 0.94 & 28 & 13 & 103 \\
\hline
\end{tabular}


plasma catecholamine concentration occurred in individual studies, but no consistent average trend could be measured indicating either that smooth halothane anaesthesia with perfect oxygenat ${ }^{\circ}$ and with normal or reduced arterial $\mathrm{pCO}_{2}$ was not accompanied by increased sympatho-adrenal activity, or that the changes which did occur were too small to be accurately assessed.

Table I shows the average values in six experiments when 10 or 20 per cent carbon dioxide was administered during/halothane anaesthesia. The fall in $\mathrm{pH}$, increase in $\mathrm{pCO}_{2}$, and moderate rise in "standard" bicarbonate, changes characteristic of the acute respiratory acidosis,-were accompanied by progressive increases in circulating noradrenalin and $x$ drenalin which occurred in all six experiments. From average levels of 0.28 and $0.33 \mu \mathrm{g} . / \mathrm{L}$., at a $\mathrm{pCO}_{2}$ of $26 \mathrm{~mm}$. $\mathrm{Hg}$, plasma noradrenalin and adrenalin increased to 0.93 and $0.71 \mu \mathrm{g} . / \mathrm{L}$. respectively at a $\mathrm{pCO}_{2}$ of $113 \mathrm{~mm}$. $\mathrm{Hg}$, to 1.3 and $1.9 \mu \mathrm{g} . / \mathrm{L}$. at a $\mathrm{pCO}_{2}$ of $141 \mathrm{~mm} . \mathrm{Hg}$, and at the final average $\mathrm{pCO}_{2}$ of $153 \mathrm{~mm}$. $\mathrm{Hg}$ plasma noradrenalin was 1.7 and adrenalin $3.6 \mu \mathrm{g} . / \mathrm{L}$. Average total plasmia catecholamine concentration in all samples withdrawn during this hour of respiratory acidosis, 3.4 ug./L., was significantly higher $(p<0.05)$ than the average level of $0.71 \mu \mathrm{g} . / \mathrm{L}$. during the previous 2 hours of uncomplicated halothane anaesthesia.

Arterial blood pressure, which was reduced during the steady state of halothane anaesthesia, showed variable changes when the arterial $\mathrm{pCO}_{2}$ increased. The following early changes were observed in different experiments-an increased systolic and lowered diastolic pressure, a rise in systolic and diastolic, or a fall in both pressures. The effects seen with 10 per cent carbon dioxide were less pronounced than with the higher concentration. Thus, in one experiment 20 per cent carbon dioxide produced an immediate and progressive fall in blood pressure which was reversed by reducing the inspired halothane concentration from 2 to 1 per cent. In another experiment (the data from which are excluded from Table 1) there was an initial rise in systolic and diastolic pressures when spontaneous respiration started, but profound hypotension and apnoea then developed, the halothane concentration remained at 2 per cent, and circulatory collapse occurred 14 min. after starting 20 per cent carbon dioxide inhalation. Total plasma catecholamine concentration had increased from $1.3 \mu \mathrm{g}$. $/ \mathrm{L}$. before hypercarbia to $4.4 \mu \mathrm{g}$. $/ \mathrm{L}$. just prior to cardiac arrest. In the third experiment in which 20 per cent carbon dioxide was given there was an initial rise in systolic and diastolic pressures, and at a later period cardiac arrhythmias were noted, this being the only occasion in seven experiments when cardiac irregularities were observed on the blood pressure tracing as $\mathrm{pCO}_{2}$ increased during halothane anaesthesia.

The most consistent circulatory changes when hypercarbia was established during halothane anaesthesia were a fall in diastolic pressure and an increased heart rate; changes in systolic pressure were more variable. Consideration of the data given in Table I shows that mean arterial blood pressure was reduced after 15,30 , and $60 \mathrm{~min}$. of increased $\mathrm{pCO}_{2}$ during halothane anaesthesia.

The effects of haemorrhage during halothane anaesthesia are shown in Table II; the data are averaged from 5 experiments. The gradual decline in $\mathrm{pH}$ and "standard" bicarbonate, at a constant level of $\mathrm{pCO}_{2}$, demonstrates the metabolic acidosis induced by haemorrhage (5). Increases in plasma adrenalin occurred 
but were not pronounced $15-20 \mathrm{~min}$. after the initial blood loss of $20 \mathrm{ml} / \mathrm{kg}$. After a second haemorrhage, which increased heart rate and reduced blood pressure to very low levels, average plasma adrenalin concentration had increased to $7.5 \mu \mathrm{g} . / \mathrm{L}$. The average circulating adrenalin level in all samples withdrawn during the steady state, $0.17 \mu \mathrm{g} . / \mathrm{L}$., was increased to $4.1 \mu \mathrm{g} . / \mathrm{L}$. during the period of haemorrhage. In one experiment the sympatho-adrenal response to haemorrhage appeared minimal, plasma adrenalin increasing from zero to only 0.32 $\mu \mathrm{g}$. L. ; by contrast, in another study a plasma adrenalin concentration of 26 $\mu \mathrm{g} . / \mathrm{L}$. was reached. In the remaining three experiments the average adrenalin level increased from $0.32 \mu \mathrm{g}$. L $\mathrm{L}$. in all samples withdrawn during the steady state, to $2.3 \mu \mathrm{g}$./L. during the period of haemorrhage. The probability that samples for estimation were not always withdrawn at a time when sympatho-adrenal responses were maximal was shown by one experiment, in which a plasma adrenalin level after haemorrhage of $2.3 \mu \mathrm{g} . / \mathrm{L}$. was increased to $6.2 \mu \mathrm{g} . / \mathrm{L}$. after a further 12 min. without additional blood loss.

Because of the wide range of values measured in this small number of experiments (resulting in a large standard. error) the increase in plasma adrenalin levels, although pronounced, was not significant at the 5 per cent level.

During halothane anaesthesia plasma noradrenalin showed much smaller increases in response to haemorthage (Table II).

\section{Discussion}

The results obtained in this study with halothane agree with previous findings in dogs lightly anaesthetized with thiopental, namely that predominant increases in plasma adrenalin occur during haemorrhagic hypotension (8) while carbon dioxide accumulation induces rises in both noradrenalin and adrenalin (10). During the hypercarbia of diffusion respiration, at a $\mathrm{pCO}_{2}$ averaging $173 \mathrm{~mm}$. $\mathrm{Hg}$ in five experiments, average total plasma catecholamine concentration was 5.7 $\mu \mathrm{g} . / \mathrm{L}$. (10). In the six experiments of the present study, at an average $\mathrm{pCO}_{2}$ of $153 \mathrm{~mm}$. Hg during halothane anaesthesia, total plasma noradrenalin and adrenalin concentration was $5.3 \mu \mathrm{g} . / \mathbb{L}$. There is clearly no evidence from the data that halothane reduces the sympatho-adrenal response to hypercarbia to an extent greater than that of light barbiturate anaesthesia.

A moderate fall in mean arterial blood pressure appears to be the usual response to established hypercarbia during halothane anaesthesia in dogs. Page and Olmsted (11), emphasizing the variability in response of arterial blood pressure to hypercarbia in anaesthetized dogs, found that controlled ventilation with carbon dioxide/oxygen mixtures during barbiturate anaesthesia produced either hypotension or hypertension initially, arterial pressure later returning to control or moderately increased levels. In regard to systolic pressure, the findings of the present study are similar, and failure of blood pressure to rise in response to hypercarbia during halothane anaesthesia cannot ibe interpreted simply as evidence of autonomic depression. Also, if ganglion blockade were an important or constant feature of halothane anaesthesia, severe hypotension might have been expected to occur as an immediate response to carbon dioxide in more than only 
one out of seven experiments since the hypotensive response to carbon dioxide has been found to increase when sympathetic ganglia are removed (11).

The design and results of this small series of experiments permit only broad conclusions concerning the effects of anaesthetic concentrations of halothane on the reflex responses to hypercarbia and haemorrhage, but it is clear that depression of sympathetic activity cannot be assumed to occur during surgical anaesthesia with this agent. Although low blood pressure states unaccompanied by significant increases in circulating catecholamine concentration during uncomplicated halothane anaesthesia may suggest autonomic depression, the increased plasma catecholamine levels induced by hypercarbia and haemorrhage imply that hypotension is not necessarily a valid indication that central or peripheral autonomic pathways are blocked; if ganglion blockade does occur during halothane anaesthesia then it appears to be incomplete, as others have stated $(2,13)$, and as clinical observations have suggested $(4)$.

\section{SLMMARY}

In an attempt to assess the sympatho-adrenal responses to hypercarbia and haemorthage during halothane anaesthesia, plasma adrenalin and noradrenalin concentrations were determined in dogs maintained in a steady state of anaesthesia by ventilation with 2 per cent halothane in oxygen. During uncomplicated halothane anaesthesia no significant increase or decrease in adrenalin or noradrenalin could be measured. Elevation of arterial $\mathrm{pCO}_{2}$ was accompanied by significant rises in plasma catecholamine levels; mean arterial blood pressure was reduced during hypercarbia. Haemorrhage induced variable increases in adrenalin, with less effect on noradrenalin. The results indicate that depression of sympathetic activity cannot be assumed to occur during surgical anesthesia with halothane.

\section{ACKNOWLEDGMENTS}

These studies were partly supported by a grant from Parke Davis \& Co. Ltd. Laboratory assistance was provided by Mrs. J. C. Joba.

\section{RÉSUMÉ}

Dans le but d'évaluer les réponses sympathico-surrénaliennes à l'hypercarbie et à l'hémorragie au cours de l'anesthésie à l'halothane, nous avons recherché chez des chiens maintenus à des niveaux d'anesthésie constants, à l'aide d'une ventilation avec de l'halothane à $2 \%$ et de l'oxygène, les concentrations d'adrénaline et de noradrénaline plasmatiques. Nous n'avons pas observé, au cours de l'anesthésie sans complication à l'halothane, ni de diminution ni d'augmentation importante de l'adrénaline ou de la noradrénaline. L'élévation du $\mathrm{pCO}_{2}$ artériel s'est accompagnée d'augmentations importantes dans le plasma des taux de catecholamine; au cours de l'hypercarbie, la pression artérielle moyenne s'est abaissée. L'hémorragie a entraîné des augmentations variables de l'adrénaline, 
mais a produit moins d'effet sur la noradrénaline. Les résultats nous permettent de constater que, au cours de l'anesthésie chirurgicale à l'halothane, on ne peut pas présumer d'une dépression de l'activité sympathique.

\section{REFERENCES}

1. Astrup, P. A Simple Electrometric Technique|for the Determination of Carbon Dioxide Tension in Blood and Plasma, Total Cóntent of Carbon Dioxide in Plasma, and Bicarbonate Content in "Separated" Plasna at a Fixed Carbon Dioxide Tension $(40 \mathrm{~mm}$. Hg). Scand. J. Clin. Lab. Invest. 8: 33 (1956).

2. Burn, J. H.; Epstein, H. G.; Feigan, G. A.; \& Paton, II. D. M. Some Pharmacological Actions of Fluothane. Brit. Med. J. 2: 479 (1957).

3. Burn, J. H., \& Epstin, H. G. Hypotension due to Halothane. Brit. J. Anaesth. 81: 199 (1959).

4. Enderby, G. E. H. Halothane and Hypotension. Anilesthesia 15: 25 (1960).

5. Gregerson, M. I. Chenical Changes in Blood during Haemorrhage and Traumatic ShockDogs. Ann. Rev. Physiol. 8: 335 (1946).

6. Johnstone, M. The Human Cardiovascular Response to Fluothane Anaesthesia. Brit. J. Anaesth. 28: 392 (1956).

7. Johnstone, M. The Role of Halothane in the Prevention of Surgical Shock. Brit. J. Anaesth. 30: 435 (1958).

8. Millak, R. A., \& Bexfey, B. G. The Fluorimetric Estimation of Adrenaline and Noradrenaline during Haemorrhagic Hy potension. Brit. J. Anaesth. $30: 159$ (1958).

9. Millar, R. A., Keentr, E. B., \& Benfer, B. G. Plasma Adrenaline and Noradrenaline after phenoxybenzamine, and during Haemorrhagic Hypotension in Normal and Adrenalectomized Dogs. Brit. J. Pharmacol. 14: 9 (1959).

10. Millar, R. A. Plasma Adrenaline and Voradrenaline during Diffusion Respiration. J. Physiol. 150: 79 (1960).

11. Page, I. H., \& Olnsted, F. The Influence of Respiratory Gas Mixtures on Arterial Presaure and Vascular Reactivity in "Normal" and Hypertensive Dogs. Circulation 8: 801 (1951).

12. Raventos, J. The Action of Fluothane: A New Volatile Anaesthetic. Brit. J. Pharmacol. $11: 394(1956)$.

13. Severtighats, J. M., \& Clliex, S. C. Depression of myocardium and body oxygen cunsumption with fluothane. Anesthesiology' 1!) 165 (11058). 